\title{
Risk Type Analysis of Building on Urban Flood Damage
}

\author{
Kiyong Park ${ }^{1}$, Sang-Hyun Choi ${ }^{2}$ and Insang Yu ${ }^{3, *(1)}$ \\ 1 School of Planning, Design \& Construction, Michigan State University, East Lansing, MI 48824, USA; \\ parkkiyo@msu.edu \\ 2 Management Information System, Department of Big Data, Chungbuk National University, \\ Cheongju 28644, Chungbuk, Korea; chois@chungbuk.ac.kr \\ 3 Korea Adaptation Center for Climate Change, Korea Environment Institute, Sejong 30121, Korea \\ * Correspondence: isyu0612@naver.com; Tel.: +82-10-5499-8567
}

Citation: Park, K.; Choi, S.-H.; Yu, I. Risk Type Analysis of Building on Urban Flood Damage. Water 2021, 13, 2505. https://doi.org/10.3390/ w13182505

Academic Editor: Juan

Antonio Ballesteros Canovas

Received: 16 July 2021

Accepted: 7 September 2021

Published: 12 September 2021

Publisher's Note: MDPI stays neutral with regard to jurisdictional claims in published maps and institutional affiliations.

Copyright: (C) 2021 by the authors. Licensee MDPI, Basel, Switzerland. This article is an open access article distributed under the terms and conditions of the Creative Commons Attribution (CC BY) license (https:/ / creativecommons.org/licenses/by/ $4.0 /)$.

\begin{abstract}
Climate change caused by global warming has resulted in an increase in average temperature and changes in precipitation pattern and intensity. Consequently, this has led to an increase in localized heavy rain which intensifies the uncertainty of the development of urban areas. To minimize flood damage in an urban area, this study aims to analyze the flood risk effect on buildings by ranking the risk of flood damage for each building type and sorting the long-term land use plan and the building type that requires particular consideration. To evaluate the flood risk of each building type, vulnerability analysis and exposure analysis were conducted in five regions of the Ulsan City. The vulnerability analysis includes determination of each building type by using the building elements which are sensitive to flood damage. In terms of the exposure analysis, environmental factors were applied to analyze the flood depth. The mapping based on the results from two analyses provided the basis for classifying the flood risk into five classes (green, yellowish green, yellow, orange, red). The results were provided in the urban spatial form for each building type. This analysis shows that the district near the Taehwa river is the area with the highest risk class buildings (red and orange class buildings). Notably, this area plays a pivotal functional role in administrating the Ulsan City and has a high density of buildings. This phenomenon is explained by city development which is centered around the lowland; however, given the high value of property, the potential risk is proven to be high.
\end{abstract}

Keywords: climate change; urban flood damage; flood risk; vulnerability; exposure

\section{Introduction}

Floods are the most common and widely distributed natural risk to life and property worldwide, and the United Nations (UN) estimates that one billion people live in areas of potential flood risk [1,2]. Worldwide, floods resulted in over 16 billion USD in damages and 1500 fatalities in 2014 alone [3]. Flooding is considered one of the most serious and widespread natural hazards due to its devastating effects that endanger lives and cause property damage in the affected areas [4-6]. Floods represent natural risk phenomena which vary in intensity, causing significant economic and human losses, and are the result of the interaction between several different anthropogenic and natural variables which are specific to an area and have different influences on the generation of these events. In the context of global climate change caused by ever-increasing anthropic activities, the intensity and frequency of these events has increased in the past years and is continuing to intensify $[7,8]$.

Population growth and the shift of people from rural to urban areas is increasing the demand for the expansion of urban areas. Rapid urbanization brings several environmental problems, such as the urban heat island effect, changes in hydrological processes and water resources, contribution to climate change, and the extinction of species [9]. Urbanization causes alterations in hydrological processes through change in surface infiltration characteristics due to an increasing impervious surface area. An increased built area results in a 
decrease in infiltration, baseflow, and lag times, and an increase in runoff volumes, peak discharge, and frequency of floods [10,11]. Human activities such as urbanization and the growth of settlements and assets in flooding areas likewise contribute to the increasing impacts of floods [12]. The risks due to such hazards in urban areas can significantly hinder daily activities, incur costly damages, and contribute to large scale life losses, which is the reason why, when such risks are realized, they are often referred to as disasters [13].

Flood damage mitigation applications can be classified into two main groups, namely, structural and non-structural measures [14]. Structural efforts focus on reducing the impact of flooding on communities by building levees, floodwalls, and improving drainage systems [15]. On the other hand, non-structural measures such as land-use control, acquisition, relocation, and early flood warning systems are preventive actions [16,17].

Urbanization on floodplains results in a rise in property values, therefore increasing potential flood damage [18]. Because flood damage is inevitable in floodplains, settling and investing in the floodplain contributes to a higher risk of flood damage [19]. Thus, a longterm flood mitigation strategy may be possible by relocating structures in the higher-risk flood zones.

This study aims to analyze urban flood risk by examining the characteristics of buildings along with the environmental factors. Prioritizing buildings with high risk within the construction risk analysis can become an economic solution for reducing the flood risk. Furthermore, analyzing the risk of key buildings that determine the urban space characteristics is potentially a practical solution for formulating an unstructured flood mitigation strategy.

\section{Methods}

This study is composed of four chapters with the following structure. In Section 2, theoretical information about the drivers and measures for flood damage along with the research background are provided. Moreover, the target regions, the concept of risk analysis, and the methodology for risk analysis are described. In Section 3, we present the vulnerability analysis performed through the database establishment, using a building as an evaluation unit. Then, we conducted hazard and exposure analysis using the terrain and precipitation data alongside building risk analysis and ultimately showed the results, including the comparative analysis output (i.e., the characteristics of each district). In Section 4 , the implications of these results are formulated while the strengths and limitations of the urban spatial elements manifested in the building characteristics are discussed. In this study, the scope was limited to the flood damage, and the spatial extent of the analysis includes the Ulsan City.

\subsection{Research Scope and Target Regions}

The flood damage drivers can be classified into natural, social, and facility factors. Another way to classify these drivers is to divide them into structural, nonstructural, and hydrometeorological factors, as shown in Figure 1. Moreover, these factors can be represented as external and internal factors. The instance of an external factor is when the localized heavy rain and sea level increase because of climate change and cause natural disasters. Meanwhile, an internal factor is when the population growth and the spread of unplanned urban development triggers a natural disaster [20]. As the correlation between these factors is continuously increasing, the scales of disasters are also broadening.

Severe disasters, such as a hurricane, are not directly driven by climate changeassociated phenomena in Korea. However, flood damage in urban areas due to heavy rain is registered every year and the scale of impact is controlled by the disaster prevention capability associated with internal factors of the city (i.e., with structural and nonstructural factors). This study performed hazard, exposure, and vulnerability analysis to investigate external and internal factors, respectively, and based on these results, comprehensively analyzed urban floods. 


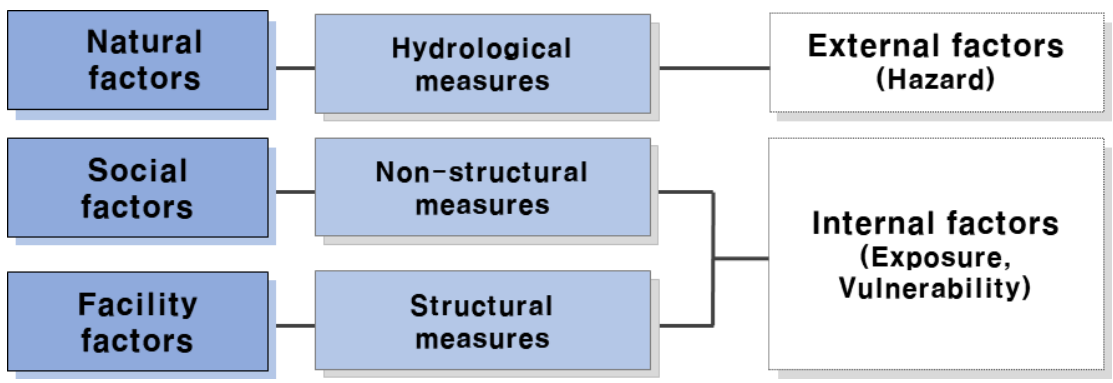

Figure 1. Cause scheme of urban flooding.

We used the annual disaster yearbooks from the Ministry of the Interior and Safety of Korea [21]. Using these yearbooks, we classified the disaster-related damage into two factors (causes and facilities, as shown in Table 1) from 2010-2019. The damage-related losses for each disaster registered in the recent ten years in Korea were 124,482 million KRW due to heavy rains (37.42\%), 3747 million KRW due to snow (1.13\%), 2068 million KRW due to winds waves $(0.62 \%), 3120$ million KRW due to strong winds $(0.94 \%), 189,382$ million KRW due to typhoons (56.94\%), and 9825 million KRW due to earthquakes (2.95\%). As typhoon-related damage is fundamentally implied in flood damage, the former was integrated into heavy rain damage. Notably, heavy rain damage (heavy rain damage with typhoon damage) has caused a loss of 313,864 million KRW, being responsible for $94.36 \%$ of the total disaster damage, thus being the most damaging factor in the analysis. Losses due to heavy rain damage for each facility in the recent ten years were 6334 million KRW for buildings (5.09\%), 62 million KRW for vessels (0.05\%), 5013 million KRW for farmlands (4.03\%), 108,739 million KRW for public facilities (87.35\%), and 124,482 million KRW for other facilities and infrastructure (37.42\%). Public facilities include not only urban infrastructure facilities (roads, parks, and water supply with drainage facilities), but also recreational, entertainment, and medical facilities (business facilities and health and welfare facilities). Therefore, public facilities were combined with buildings. Thus, the drivers of flood damage were classified into external and internal factors while the urban flood risk was analyzed. As an external factor, we selected a heavy rain event which caused the highest damage (in percentage) in the recent ten years (94.36\%). As an internal factor, buildings with the highest damage percentage of $92.44 \%$ were selected.

Table 1. Damage caused and facilities by natural disasters (2010-2019) in Korea [21].

\begin{tabular}{|c|c|c|c|c|c|c|c|c|c|c|c|c|}
\hline & \multicolumn{2}{|c|}{ Building } & \multicolumn{2}{|c|}{ Vessel } & \multicolumn{2}{|c|}{ Farmland } & \multicolumn{2}{|c|}{ Public Facilities } & \multicolumn{2}{|c|}{ etc. } & \multicolumn{2}{|c|}{ Total } \\
\hline & Damage & $\%$ & Damage & $\%$ & Damage & $\%$ & Damage & $\%$ & Damage & $\%$ & Damage & $\%$ \\
\hline Heavy rain & 6334 & 5.09 & 62 & 0.05 & 5013 & 4.03 & 108,739 & 87.35 & 4334 & 3.48 & 124,482 & 37.42 \\
\hline Heavy snowfall & 137 & 3.66 & 26 & 0.69 & 0 & 0.00 & 1474 & 39.34 & 2110 & 56.31 & 3747 & 1.13 \\
\hline Wind wave & 49 & 2.37 & 15 & 0.73 & 52 & 2.51 & 957 & 46.28 & 995 & 48.11 & 2068 & 0.62 \\
\hline Strong wind & 38 & 1.22 & 36 & 1.15 & 0 & 0.00 & 312 & 10.00 & 2734 & 87.63 & 3120 & 0.94 \\
\hline Typhoon & 5785 & 3.05 & 956 & 0.50 & 3196 & 1.69 & 125,227 & 66.12 & 54,218 & 28.63 & 189,382 & 56.94 \\
\hline Earthquake & 6368 & 64.81 & 0 & 0.00 & 0 & 0.00 & 3446 & 35.07 & 11 & 0.11 & 9825 & 2.95 \\
\hline Total & 18,711 & 5.63 & 1095 & 0.33 & 8261 & 2.48 & 240,155 & 72.20 & 64,402 & 19.36 & 332,624 & 100.00 \\
\hline
\end{tabular}

Ulsan City was selected as the target area of this study and is shown in Figure 2. Ulsan City can be divided into five administrative districts: Jung-gu, Nam-gu, Dong-gu, Buk-gu, and Ulju-gun. Ulsan City has a total population of 1,150,294 and an area of $1061.54 \mathrm{~km}^{2}$ for a population density of 1083 persons $/ \mathrm{km}^{2}$. The city includes urban, farming, and coastal areas [22] with an annual average temperature of $13.8^{\circ} \mathrm{C}$ and an annual average precipitation of $1274.6 \mathrm{~mm}$, where $70 \%$ of the rainfall is concentrated between June and September, forming a vulnerable hydrologic condition. Because of the high elevation in the west and low elevation in the east, the Taehwa River flows from west to east across 
Ulsan City. On 5 October 2016, Typhoon Chaba caused the deaths of three people and approximately 61 million USD of property damage [21]. Ulsan City was selected as the target area as it recently experienced enormous flood damage, includes urban, farming, and coastal areas, national and local streams, and has geographical and hydrological conditions that are vulnerable to flooding [23].

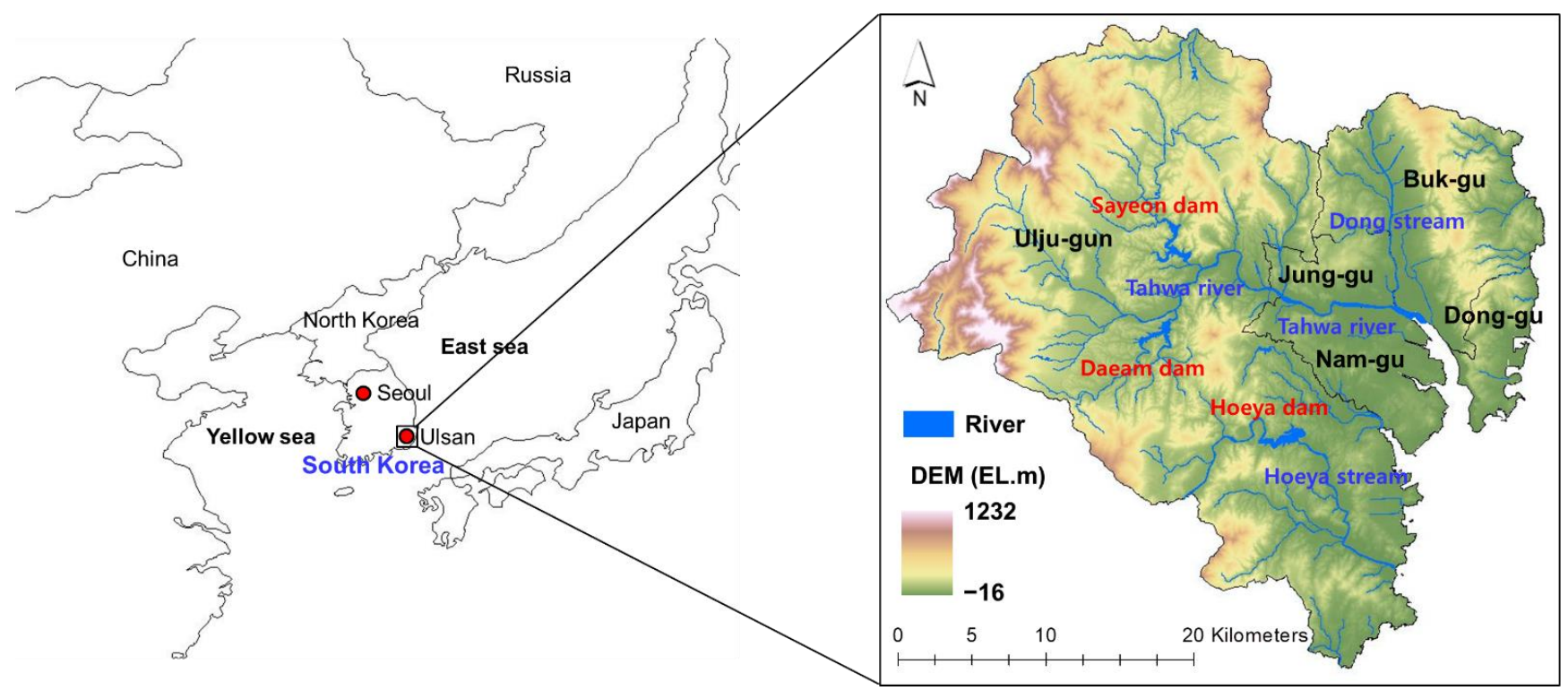

Figure 2. Target regions of Ulsan City in Korea.

\subsection{Building Measures to Prevent Urban Flooding}

Flood damage was divided into consequences including loss of life, loss of property, and damage to urban functions. Depending on the damage subject, loss of property and damage to urban functions accounted for more damage than loss of life because most flood damage is caused by weather conditions such as heavy rain or storms and involves a certain degree of predictability [24].

Table 2 provides an overview of the structural and non-structural measures that can be used to cope with floods. In the long run, preparedness and non-structural adaptations are more efficient and sustainable solutions to flood-related problems to reduce the vulnerability of citizens and goods exposed to flood risk [25].

Structural measures are divided into extensive and intensive measures. The extensive structural measures include reshaping of land surface, soil conservation, flow delay, and increase of infiltration. The intensive measures consist of four categories: levees and dikes, water storage, increase in channel flow capacity, and floodplain polders and platforms. Increasing water storage ponds as intensive structural measures highly affect floods [26]. There are three categories of non-structural measures: (a) regulation for proofing of floodplains (zoning, coding); (b) defense from floods (education and awareness, forecasting, warning, flood proofing, evacuation, relocation); and (c) fiscal strategies (insurance, grant, a referendum to dedicate funding). Zoning or land use policies and regulations, such as development restriction, clustering, density bonuses, and transfer of development rights, can reduce the negative impacts of flood events by directing growth away from susceptible areas. Proactive land use planning strategies that steer development away from vulnerable areas can not only reduce flood damage, but also protect critical natural habitats and water quality [27]. 
Table 2. Overview of structural and non-structural measures to cope with floods: classification [28].

\begin{tabular}{cll}
\hline $\begin{array}{c}\text { Measures to Cope with } \\
\text { Floods }\end{array}$ & \multicolumn{1}{c}{ Structural } & Non-Structural \\
& Extensive & Regulation \\
& -reshaping of land surface & -zoning/land use planning \\
& -protection from erosion & -coding \\
& -delay of runoff processes & Flood defense \\
& -increase of infiltration & -education and awareness \\
& -urban works & -flood forecasting/warning \\
& -levees, dikes, floodwalls & -flood proofing \\
& -dams and reservoirs & -evacuation \\
& -floodways and diversion works & Fiscal strategies \\
& -polders and fills & -insurance or grant (governmental, private, mixed) \\
& -drainage works & -a referendum to dedicate \\
& -runoff delay and increase of & funding for flood mitigation \\
& infiltration & -no significant environmental changes \\
& -flood attenuation & -improved organizational \\
& -downstream discharge control & relations \\
& -groundwater control & -effectivity in dealing with flood impacts and \\
& -reduction of floodplain fertility & damages \\
& -high potential of ecological impacts & -rise of property value and invasion of floodplains \\
& -land subsidence & -higher level of insurance coverage needed
\end{tabular}

General measures can be used to minimize damage from urban flooding, including structural measures, but recently because of the uncertainty of torrential rains, defense capacity has been limited. Because structural measures in the form of temporary responses are limited, the problem must be approached spatially and systematically by analyzing land use and building measures, which are largely unstructured measures [23].

The Federal Emergency Management Agency (FEMA) of the Department of Homeland Security (DHS) of the United States established the system that exclusively assesses the risk level of buildings associated with terrorism (RVS) after 11 September 2001. In the aftermath, the FEMA has been continuously developing guidelines for buildings, risk evaluation systems, a risk management manual in terms of risk management of buildings for several disaster scenarios such as earthquakes, fire, floods, and typhoons, which are unrelated to terrorism. The RVS system was further expanded to be applied for general buildings as an evaluation system (IRVS) which can be used for risk analysis for several disasters and for comprehensive analysis of building recovery in 2011 to counteract the disaster risk.

Korea has also recognized the importance of protecting buildings from disaster-related risks and has prepared the legal basis by enacting the (Special Act on Disaster Management of High-Rise and Underground Connected Complex Buildings) on 27 March 2018. However, the architectural measures for reinforcing the disaster management of buildings are focused on evacuation plans. In particular, the high-rise disaster management act renders that it is strictly necessary to review the pre-disaster impact on the installation of an evacuation safety zone and the adequacy of evacuation inducement plan. Such policy has a strong inclination towards a follow-up plan focusing on post-disaster occurrence rather than a preventative measure. The review document depicting pre-disaster impact contains guidelines that need to be applied uniformly. Moreover, building owners or architects need to accurately consider reducing the risk of building at an initial design stage, given special circumstances of the disaster, while proposing effective and comprehensive resource utilization depending on the disaster risk.

The intensification of urban functionality and urban densification lead to the redevelopment of underdeveloped areas of old towns (and downtowns), while the construction of technologically complex buildings is increasing in central business areas. If flooding 
takes place in an urban area where buildings with high property value and populations are concentrated, the physical loss of building properties and loss of lives are more severe. In such cases, disaster and damage prevention are preferred over mitigating the disastrous impacts. Therefore, the risk evaluation of buildings against flood risk, direction of the plan, and management system have to be established in nonstructural terms by preparing constructional measures for the disaster prevention.

\subsection{Risk Analysis of Urban Flood}

The Intergovernmental Panel on Climate Change (IPCC) Fifth Assessment Report (AR5), published in 2014, has introduced a new concept which aims to identify and evaluate the risk of impacts from climate change. It was adopted from the concepts and practices of carrying out risk assessments in the Disaster Risk Reduction community. Thus, it greatly overlaps with the way in which scientists and practitioners address natural hazards such as earthquakes, floods, or landslides.

Disaster was assessed according to the conceptualization of vulnerability in the Fourth Assessment Report (AR4) of the IPCC. In IPCC AR5, vulnerability evolved into the concept of risk [29]. In this study, the concept of risk from IPCC AR5 was used to develop a model for deriving a disaster risk index and map. We agree that a conceptualization of disaster risk should consider all aspects of disasters including hazard, exposure, and vulnerability, as well as all time periods, as shown in Figure 3. Based on the concept, disaster risk was assessed on the basis of its hazard, exposure, and vulnerability features [30].

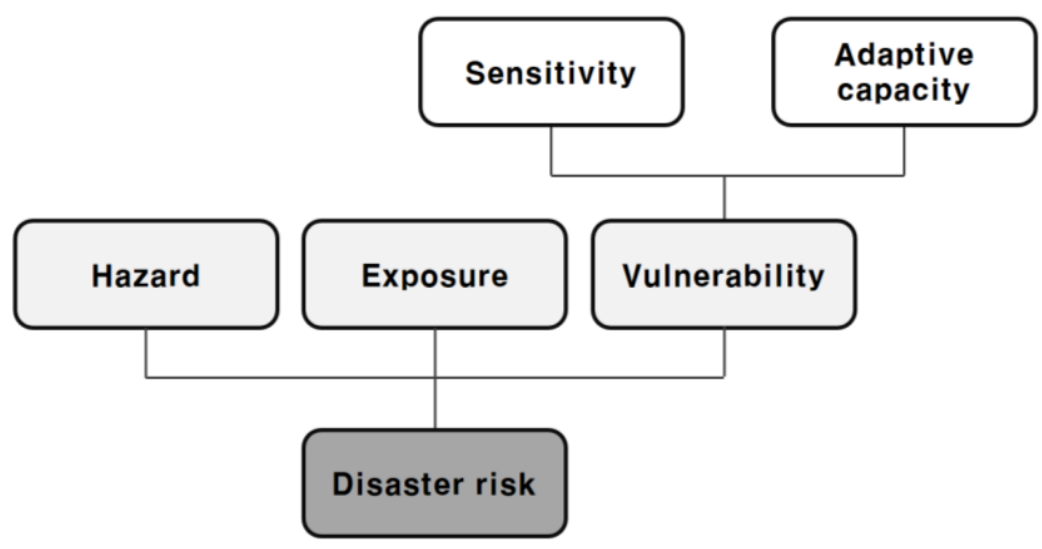

Figure 3. Flow chart of disaster risk framework [29].

The IPCC AR5 risk concept has been developed around the central term 'risk'. In this concept, risk is a result of the interaction of vulnerability, exposure, and hazard (Figure 4) [29]. The risk of climate-related impacts results from the interaction of climaterelated hazards (including hazardous events and trends) with the vulnerability and exposure of human and natural systems. 


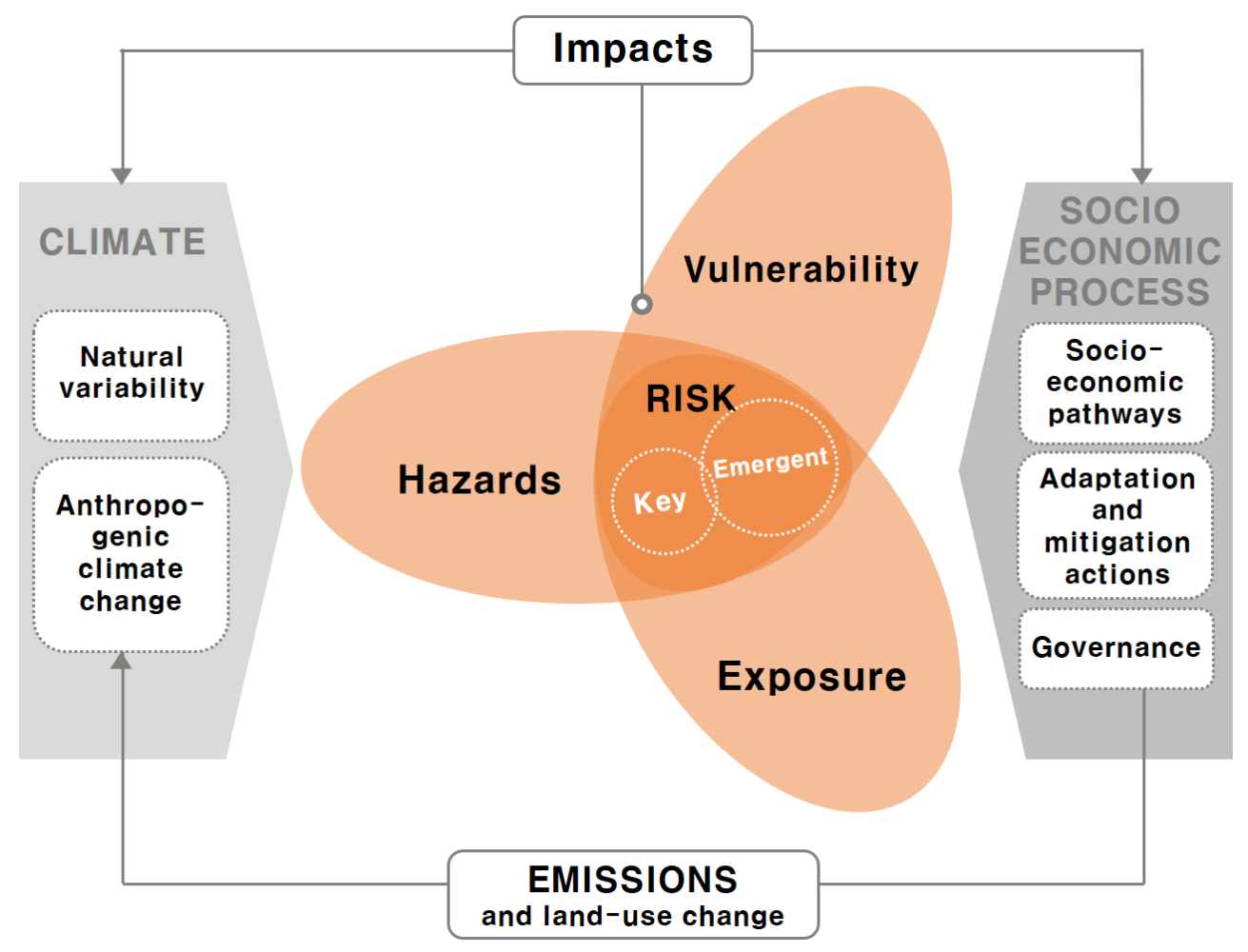

Figure 4. Flood risk concept [29].

In this study, vulnerability is considered to be independent from disaster characteristics and is taken as a feature depending on the building (land use) shape. It means that there is even sensitivity of the wetted area due to social or economic factors. Hazard determines the proportion of the wetted area in the analyzed area in case of heavy rain and is defined as the average of the area for habitual heavy rain and ideal heavy rain. Exposure is a factor that has a direct effect on flood damage, and it directly induces flood damage.

The risk of a flood disaster is essentially an uncertainty problem, and quantitative expression is the premise for solving this uncertainty problem [31].

In the Eurac (2017) [32] study, risk was expressed using the following equation: Risk $=$ Hazard + Vulnerability + Exposure. This definition was exploited to analyze the flood risk, and the method we use in this study is shown in Figure 5 (to analyze the flood risk associated with the urban flood damage). For the urban flood risk analysis (building is an evaluation unit), the formula proposed in the Eurac (2017) [32] study was applied, whereas the exposure value in Hazard is additionally provided. The analysis is performed following the steps shown below.

(1) Vulnerability analysis provides a non-structural factor index, which is a buildingrelated feature. It represents the magnitude of social and economic damage of a building due to flood (expressed in a building as a unit).

(2) The empirical analysis on the flood depth and wetted area uses the precipitation and terrain data to show what the disaster characteristics are, including the exposure. It considers the basic environmental factors and analyzes the flooded area through the Hec-Ras (Hydrologic Engineering Center's River Analysis System).

(3) The flood risk is provided as a function of vulnerability (a building unit) and as hazard/exposure, which are the flooded area analysis data. Subsequently, the value for each building is retrieved, and mapped. The evaluation and analysis are performed by establishing the flood risk evaluation model expressing the characteristics of the building included in the nonstructural measures.

(4) Finally, the areas with high and low risks are analyzed in comparison using a scientific method that relies on the urban flood risk evaluation results. 


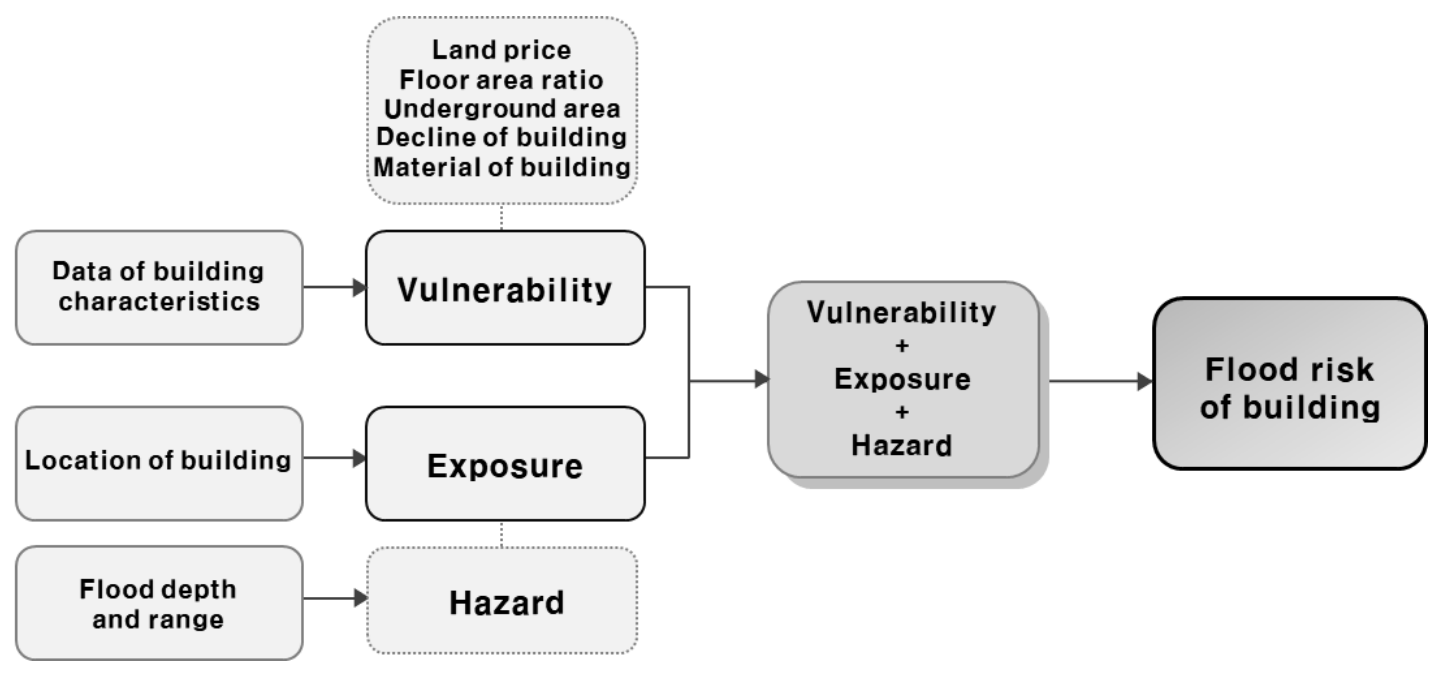

Figure 5. Analysis framework of flood risk building.

\section{Results and Discussion}

\subsection{Unit of Analysis for Flood Risk Building}

To investigate the urban spatial characteristics, including the nonstructural characteristics (building as a unit), the urban flood vulnerability of each building was analyzed after attributing the weighting based on the following indices: land price, floor area ratio, underground area, decline of building, and material of building through fuzzy analysis. The official land value of each building was estimated by the Ulsan City data by the Korea Appraisal Board. Meanwhile, for the floor area ratio, underground space, building year, and building material, 108,256 estimates were provided for each building and for (as shown in Table 3) each index used for analysis that involves the building register established in the Ulsan City [23]. Furthermore, as the regional characteristics vary depending on a district, the analysis was conducted after dividing the city of interest into the Jung-gu, Nam-gu, Dong-gu, Buk-gu, and Ulju-gun districts.

Table 3. Database for building unit [23].

\begin{tabular}{|c|c|c|c|c|c|c|}
\hline $\begin{array}{l}\text { Building } \\
\text { (Total \# of } \\
\text { Items) }\end{array}$ & \# of Items & $\begin{array}{l}\text { Land Price } \\
\left(\text { won } / \mathbf{m}^{2}\right)\end{array}$ & $\begin{array}{c}\text { Floor Area } \\
\text { Ratio (\%) }\end{array}$ & $\begin{array}{l}\text { Underground } \\
\text { Area }\left(\mathrm{m}^{2}\right)\end{array}$ & $\begin{array}{l}\text { Decline of } \\
\text { Building }\end{array}$ & $\begin{array}{l}\text { Material of } \\
\text { Building }\end{array}$ \\
\hline \multirow{17}{*}{$\begin{array}{c}\text { Ulsan City } \\
(108,256)\end{array}$} & 1 & $1,863,000.00$ & 34.37 & 266.73 & 25.00 & 2.00 \\
\hline & 2 & $1,836,781.33$ & 232.33 & 545.82 & 27.00 & 2.00 \\
\hline & 3 & $698,259.83$ & 132.30 & 97.80 & 21.00 & 3.00 \\
\hline & 4 & $3,109,091.79$ & 393.62 & 230.86 & 16.00 & 2.00 \\
\hline & 5 & $1,414,109.96$ & 171.39 & 155.32 & 27.00 & 2.00 \\
\hline & 6 & $2,581,845.41$ & 176.12 & 112.88 & 28.00 & 2.00 \\
\hline & 7 & $1,610,000.00$ & 242.66 & 159.56 & 25.00 & 2.00 \\
\hline & 8 & $250,400.00$ & 13.06 & 3325.54 & 12.00 & 2.00 \\
\hline & 9 & $732,910.08$ & 83.87 & 106.92 & 25.00 & 3.00 \\
\hline & 10 & $1,502,000.00$ & 176.58 & 161.76 & 23.00 & 2.00 \\
\hline & 11 & $1,900,445.34$ & 154.44 & 133.59 & 22.00 & 2.00 \\
\hline & 108,251 & $1,210,146.45$ & 199.59 & 314.92 & 15.00 & 2.00 \\
\hline & 108,252 & $2,068,147.79$ & 142.41 & 205.60 & 24.00 & 2.00 \\
\hline & 108,253 & $1,937,312.37$ & 248.03 & 101.46 & 25.00 & 2.00 \\
\hline & 108,254 & $4,843,000.00$ & 736.21 & 462.00 & 8.00 & 2.00 \\
\hline & 108,255 & $1,690,000.00$ & 259.24 & 172.29 & 23.00 & 2.00 \\
\hline & 108,256 & $5,273,000.00$ & 207.44 & 3616.64 & 21.00 & 1.00 \\
\hline
\end{tabular}




\subsection{Vulnerability Analysis for Urban Flood Building}

In the Park and Yu (2020) [23] study, we applied the fuzzy methodology (a method to conduct the decision-making based on the data built using a statistical method) to analyze the urban flood vulnerability. The fuzzy model uses a building as an evaluation unit and was designed based on the data on the official land value, floor area ratio, basement area, building year, and building material built for different characteristics of a building. The fuzzification was performed using these input parameters. The higher fuzzy value indicates higher vulnerability to the flood damage, while a lower fuzzy value indicates the lower vulnerability to the flood damage. Using fuzzy model analysis, five regions of the Ulsan City (Jung-gu, Nam-gu, Dong-gu, Buk-gu, and Ulju-gun) were classified as shown in Table 4. The rate of risk vulnerability associated with the social, economic, and physical risks during flooding was analyzed for buildings in each region. The fuzzy value for each building was then retrieved based on the fuzzy analysis results through the standardized value of each index about the building characteristics for flood damage.

Table 4. Fuzzy for building unit.

\begin{tabular}{|c|c|c|c|c|c|c|c|}
\hline \multicolumn{2}{|c|}{ Administrative Districts } & $\begin{array}{l}\text { Land Price } \\
\left(\text { won } / \mathrm{m}^{2}\right)\end{array}$ & $\begin{array}{c}\text { Floor Area } \\
\text { Ratio (\%) }\end{array}$ & $\begin{array}{c}\text { Underground } \\
\text { Area }\left(\mathrm{m}^{2}\right)\end{array}$ & $\begin{array}{c}\text { Decline of } \\
\text { Building }\end{array}$ & $\begin{array}{c}\text { Material of } \\
\text { Building }\end{array}$ & Fuzzy Score \\
\hline \multirow{3}{*}{ Jung-gu } & Maximum & $6,463,180$ & 696.22 & $26,416.26$ & 149.00 & 4.00 & 0.92 \\
\hline & Minimum & 959,470 & 0.08 & 13.60 & 2.00 & 1.00 & 0.10 \\
\hline & Mean & 1167 & 123.80 & 262.70 & 30.15 & 2.67 & 0.49 \\
\hline \multirow{3}{*}{ Nam-gu } & Maximum & $12,200,000$ & 2194.33 & $1,512,911.46$ & 136.00 & 4.00 & 0.94 \\
\hline & Minimum & 1153 & 0.0018 & 2.01 & 2.00 & 1.00 & 0.10 \\
\hline & Mean & $1,101,654$ & 140.05 & 442.89 & 26.00 & 2.20 & 0.49 \\
\hline \multirow{3}{*}{ Dong-gu } & Maximum & $3,133,527$ & 2547.6 & $13,735.52$ & 108 & 4.00 & 0.92 \\
\hline & Minimum & 154.73 & 0.01 & 19.27 & 2 & 1.00 & 0.15 \\
\hline & Mean & 930,410 & 135.26 & 383.71 & 24.68 & 2.42 & 0.92 \\
\hline \multirow{3}{*}{ Buk-gu } & Maximum & $4,151,378$ & 551.17 & $56,506.47$ & 153.00 & 4.00 & 0.78 \\
\hline & Minimum & 104 & 0.01 & 3.41 & 2.00 & 1.00 & 0.10 \\
\hline & Mean & 614,318 & 81.146 & 906.62 & 23.72 & 2.36 & 0.49 \\
\hline \multirow{3}{*}{ Ulju-gun } & Maximum & $3,339,000$ & 827.43 & $37,660.44$ & 229.00 & 4.00 & 0.50 \\
\hline & Minimum & 188 & 0.01 & 3.72 & 1.00 & 1.00 & 0.10 \\
\hline & Mean & 308,655 & 56.57 & 813.20 & 26.51 & 2.33 & 0.50 \\
\hline
\end{tabular}

The urban flood vulnerability analysis results are given in Table 5 . The fuzzy values revealed the vulnerability level of each building with regard to flood damage split into five stages. We classified the buildings according to their vulnerability level using different color codes (very low vulnerability—green, low vulnerability—lime green, medium vulnerability-yellow, high vulnerability—orange and very high vulnerability-red). The results of the vulnerability analysis are shown on the map of the Ulsan City in Figure 6.

Table 5. Classification by building on urban flood vulnerability [23].

\begin{tabular}{|c|c|c|c|c|c|c|c|c|c|c|c|}
\hline \multirow[b]{2}{*}{$\begin{array}{l}\text { Administrative } \\
\text { Districts }\end{array}$} & \multirow[b]{2}{*}{$\begin{array}{l}\text { Total \# of } \\
\text { Buildings }\end{array}$} & \multicolumn{2}{|c|}{ Green } & \multicolumn{2}{|c|}{ Yellowish Green } & \multicolumn{2}{|c|}{ Yellow } & \multicolumn{2}{|c|}{ Orange } & \multicolumn{2}{|l|}{ Red } \\
\hline & & $\begin{array}{c}\text { \# of } \\
\text { Buildings }\end{array}$ & $\%$ & $\begin{array}{c}\text { \# of } \\
\text { Buildings }\end{array}$ & $\%$ & $\begin{array}{c}\text { \# of } \\
\text { Buildings }\end{array}$ & $\%$ & $\begin{array}{c}\text { \# of } \\
\text { Buildings }\end{array}$ & $\%$ & $\begin{array}{c}\text { \# of } \\
\text { Buildings }\end{array}$ & $\%$ \\
\hline Jung-gu & 24,059 & 1297 & 5.39 & 835 & 3.47 & 20,842 & 86.63 & 234 & 0.97 & 851 & 3.54 \\
\hline Nam-gu & 24,302 & 2567 & 10.56 & 821 & 3.38 & 19,221 & 79.09 & 578 & 2.38 & 1115 & 4.59 \\
\hline Dong-gu & 10,343 & 808 & 7.81 & 216 & 2.09 & 9073 & 87.72 & 89 & 0.86 & 157 & 1.52 \\
\hline Buk-gu & 11,909 & 543 & 4.56 & 209 & 1.75 & 11,098 & 93.19 & 26 & 0.22 & 33 & 0.28 \\
\hline Ulju-gun & 37,643 & 570 & 1.51 & 11 & 0.03 & 37,062 & 98.46 & - & - & - & - \\
\hline
\end{tabular}




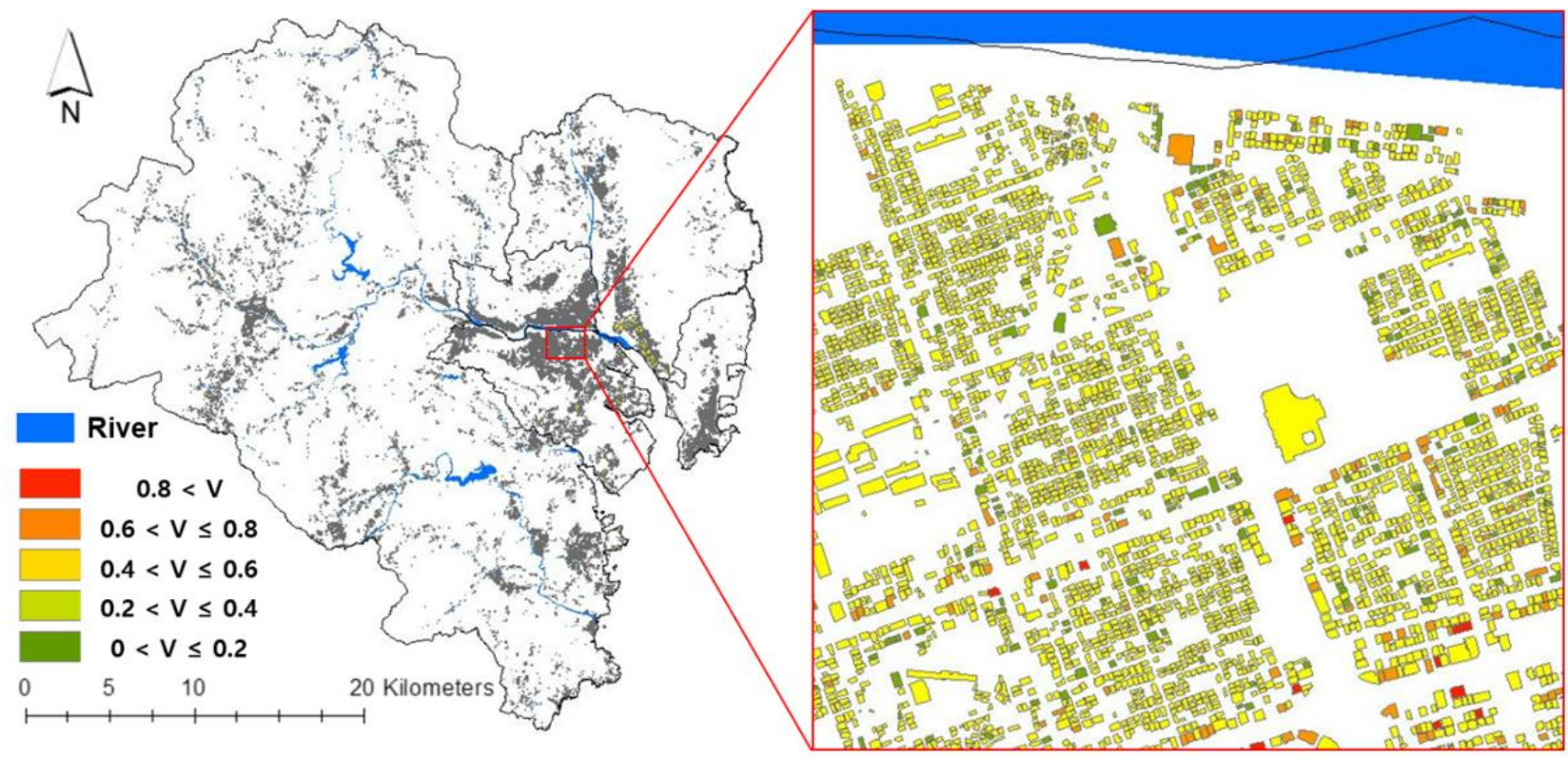

Figure 6. Vulnerability analysis for urban flood building.

\subsection{Hazard and Exposure Analysis for Urban Flood}

The hazard was analyzed using the $30 \mathrm{~m}$ flood map developed using Hec-HMS and Hec-RAS software through the "Insurance Rate Making and Mapping based on Natural Disaster Risk" project of the Ministry of the Interior and Safety. The project by Ministry of the Interior and Safety calculated the probability of rainfall through frequency analysis as input data for rainfall-runoff analysis, and constructed watershed parameters using a $30 \mathrm{~m}$ grid-based digital elevation model, land use, and soil map. Hydraulic modeling and the flood map were prepared by using information such as flow discharge calculated through rainfall-runoff simulation, river cross section, coefficient of roughness, and levee as input data of HEC-RAS. The Taehwa River basin area was the largest among the major rivers in Ulsan, the 100-year probability of rainfall was $398.9 \mathrm{~mm}$, and the discharge from the basin outlet was $4713 \mathrm{~m}^{3} / \mathrm{s}$. The watershed area and probability of rainfall and discharge according to return period are shown in Table 6. The flood map was developed based on the 100-year scenario, which is the design frequency of the river.

Table 6. Rainfall and discharge according to return period by river and stream.

\begin{tabular}{|c|c|c|c|c|c|c|c|c|c|}
\hline \multirow[b]{2}{*}{$\begin{array}{c}\text { Return } \\
\text { Period (Year) }\end{array}$} & \multicolumn{3}{|c|}{ Taehwa River } & \multicolumn{3}{|c|}{ Dong Stream } & \multicolumn{3}{|c|}{ Hoeya Stream } \\
\hline & $\begin{array}{l}\text { Watershed } \\
\text { Area }\left(\mathrm{km}^{2}\right)\end{array}$ & 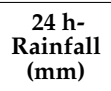 & $\begin{array}{c}\text { Discharge } \\
\left(\mathrm{m}^{3} / \mathrm{s}\right)\end{array}$ & $\begin{array}{l}\text { Watershed } \\
\text { Area }\left(\mathrm{km}^{2}\right)\end{array}$ & 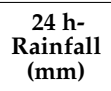 & $\begin{array}{c}\text { Discharge } \\
\left(\mathrm{m}^{3} / \mathrm{s}\right)\end{array}$ & $\begin{array}{c}\text { Watershed } \\
\text { Area }\left(\mathbf{k m}^{2}\right)\end{array}$ & $\begin{array}{c}24 \mathrm{~h}- \\
\text { Rainfall } \\
(\mathrm{mm})\end{array}$ & $\begin{array}{c}\text { Discharge } \\
(\mathrm{c} / \mathrm{s})\end{array}$ \\
\hline 50 & \multirow{4}{*}{649.26} & 345.6 & 4063 & \multirow{4}{*}{163.56} & 308.7 & 1154 & \multirow{4}{*}{218.85} & 452.9 & 2137 \\
\hline 80 & & 381.3 & 4499 & & 331.3 & 1281 & & 499.8 & 2378 \\
\hline 100 & & 398.9 & 4713 & & 342.1 & 1344 & & 522.8 & 2497 \\
\hline 200 & & 456.5 & 5423 & & 375.2 & 1552 & & 598.3 & 2893 \\
\hline
\end{tabular}

As a result of hazard analysis, the average flood depth for each administrative district was calculated to be in the range of $0.47 \mathrm{~m}$ to $1.20 \mathrm{~m}$, and the inundated area was calculated to be 0.01 to 11.71 , and the inundated area ratio was calculated to be $0.04 \%$ to $7.00 \%$ as shown in Table 7. Exposure analyses show 8469 buildings out of 24,302 buildings in Nam-gu were exposed to flooding, and the highest exposure was calculated among the five administrative districts. It was analyzed that 22,335 buildings, $20.6 \%$ of the total 108,256 buildings in Ulsan City were exposed to flooding, as shown in Table 8. 
Table 7. Analysis results of hazard (100-year flood map).

\begin{tabular}{|c|c|c|c|c|c|c|}
\hline \multirow{2}{*}{$\begin{array}{l}\text { Administrative } \\
\text { Districts }\end{array}$} & \multicolumn{3}{|c|}{ Flood Depth(m) } & \multirow{2}{*}{$\begin{array}{c}\text { Administrative } \\
\text { Districts Area }\left(\mathbf{k m}^{2}\right)\end{array}$} & \multirow{2}{*}{$\begin{array}{l}\text { Inundated } \\
\text { Area }\left(\mathrm{km}^{2}\right)\end{array}$} & \multirow{2}{*}{$\begin{array}{c}\text { Inundated } \\
\text { Area Ratio (\%) }\end{array}$} \\
\hline & Mean & Max. & Min. & & & \\
\hline Jung-gu & 1.20 & 6.14 & 0.00 & 158 & 7.27 & 4.61 \\
\hline Nam-gu & 0.47 & 1.48 & 0.01 & 36 & 0.01 & 0.04 \\
\hline Dong-gu & 0.73 & 4.70 & 0.00 & 37 & 2.35 & 6.35 \\
\hline Buk-gu & 0.82 & 2.21 & 0.01 & 71 & 5.00 & 7.00 \\
\hline Ulju-gun & 1.07 & 9.59 & 0.00 & 754 & 11.71 & 1.55 \\
\hline
\end{tabular}

Table 8. Analysis results of exposure (exposed buildings to 100-year flood).

\begin{tabular}{cccc}
\hline $\begin{array}{c}\text { Administrative } \\
\text { Districts }\end{array}$ & The Number of Buildings & $\begin{array}{c}\text { The Number of Exposed } \\
\text { Buildings }\end{array}$ & Exposed Buildings Ratio (\%) \\
\hline Jung-gu & 24,059 & 6736 & 28.0 \\
Nam-gu & 24,302 & 8469 & 34.8 \\
Dong-gu & 10,343 & 40 & 0.4 \\
Buk-gu & 11,909 & 2962 & 24.9 \\
Ulju-gun & 37,643 & 4128 & 11.0 \\
Total & 108,256 & 22,335 & 20.6 \\
\hline
\end{tabular}

The urban flood map is shown in Figure 7, whereas we demonstrated that the exposure analysis results are significantly affected by the topographic factors. Additionally, Jung-gu, an eastern district of the Ulsan City (adjacent to Taehwa river and streamlets along with the boundary region on the right side of the Nam-gu district) showed a high flood depth. The Ulsan City Hall that is located at the lowland of the Ulsan City in the downtown area (also in close vicinity to the Ulsan port) also has a high flood depth.

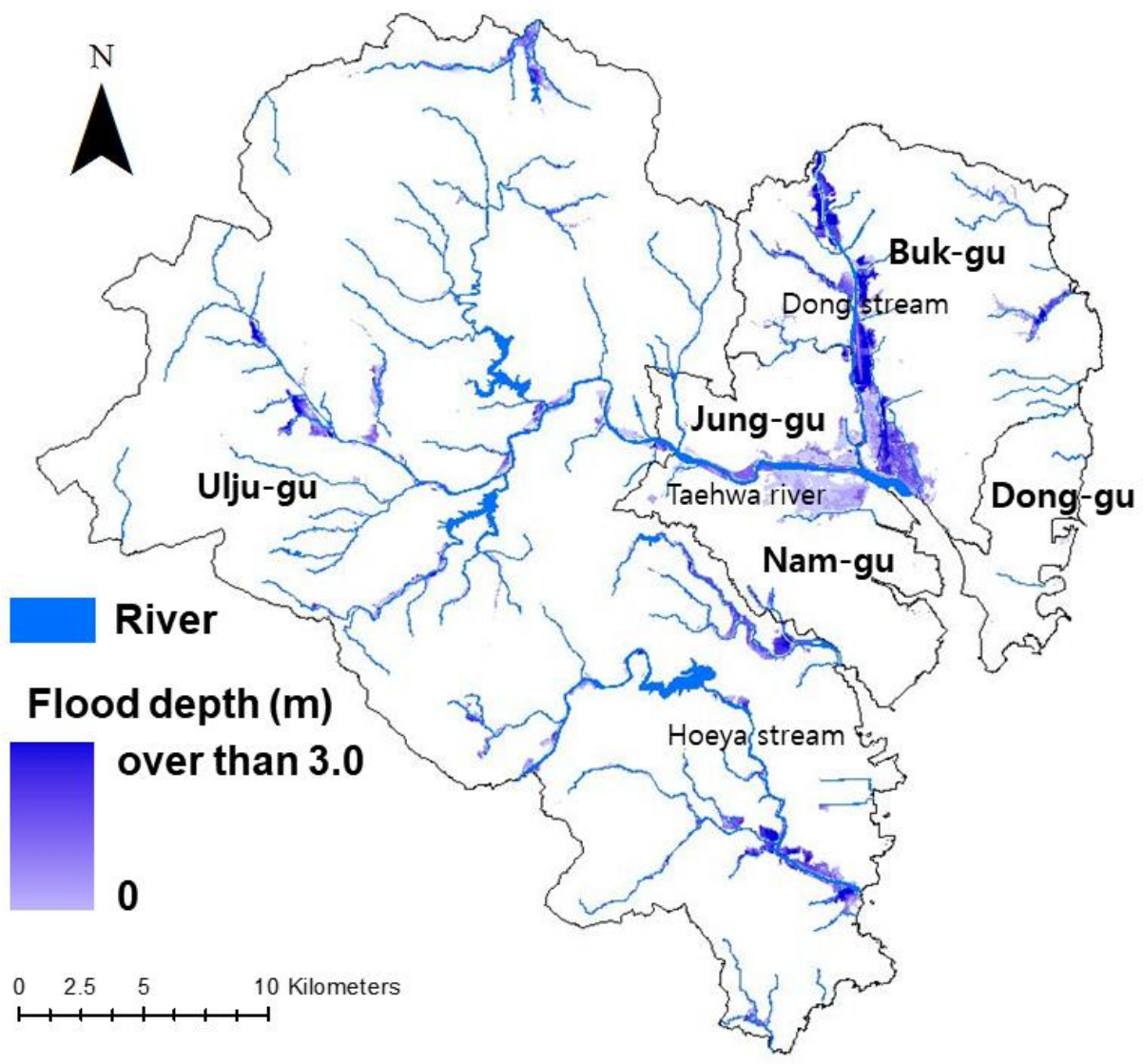

Figure 7. Hazard for urban flood. 


\subsection{Risk Analysis for Urban Flood Building}

The urban flood risk analysis for each building (that was described above) was performed using the "Risk = Hazard + Vulnerability + Exposure" calculation formula based on the Eurac (2017) [32] study. The exposure analysis map demonstrating the flood depth was created using the vulnerability analysis map based on the nonstructural factors including the urban spatial elements (criteria of social and economic damage, and the data on the precipitation and terrain including the hazard). We ranked the urban flood risk by using five predefined classes as shown in Table 9 and Figure 8. Seven regions with high flood risk, because the building class was not expressed, were omitted from Figure 8, but are clearly indicated by enlarging them in Figure 9. We analyzed urban flood risk of each building and found that red and orange classes form a triangular-shaped cluster encompassing the Jung-gu, Buk-gu, and Nam-gu districts and being centered around the Taehwa river. The emergence of this cluster is explained by the high-density of business and industrial areas in these districts (and also public institutions with key governance functions of the city). Since the major administrative management activities are conducted in these districts, the social and economic value of the properties is high in this area.

Table 9. Classification by building on urban flood risk.

\begin{tabular}{|c|c|c|c|c|c|c|c|c|c|c|c|}
\hline \multirow{2}{*}{$\begin{array}{l}\text { Administrative } \\
\text { Districts }\end{array}$} & \multirow{2}{*}{$\begin{array}{l}\text { Total \# of } \\
\text { Buildings }\end{array}$} & \multicolumn{2}{|l|}{ Green } & \multicolumn{2}{|c|}{$\begin{array}{c}\text { Yellowish } \\
\text { Green }\end{array}$} & \multicolumn{2}{|l|}{ Yellow } & \multicolumn{2}{|c|}{ Orange } & \multicolumn{2}{|l|}{ Red } \\
\hline & & $\begin{array}{c}\text { \# of } \\
\text { Buildings }\end{array}$ & $\%$ & $\begin{array}{c}\text { \# of } \\
\text { Buildings }\end{array}$ & $\%$ & $\begin{array}{c}\text { \# of } \\
\text { Buildings }\end{array}$ & $\%$ & $\begin{array}{c}\text { \# of } \\
\text { Buildings }\end{array}$ & $\%$ & $\begin{array}{c}\text { \# of } \\
\text { Buildings }\end{array}$ & $\%$ \\
\hline Jung-gu & 24,059 & 17,131 & 71.2 & 192 & 0.8 & 1880 & 7.8 & 4433 & 18.4 & 423 & 1.8 \\
\hline Nam-gu & 24,302 & 15,419 & 63.4 & 414 & 1.7 & 1924 & 7.9 & 6388 & 26.3 & 157 & 0.6 \\
\hline Dong-gu & 10,343 & 10,187 & 98.5 & 116 & 1.1 & 40 & 0.4 & 0 & 0 & 0 & 0 \\
\hline Buk-gu & 11,909 & 8936 & 75.0 & 11 & 0.1 & 386 & 3.2 & 1564 & 13.1 & 1012 & 8.5 \\
\hline Ulju-gun & 37,643 & 33,515 & 89.0 & 0 & 0.0 & 923 & 2.5 & 2387 & 6.3 & 818 & 2.2 \\
\hline Total & 108,256 & 85,188 & 78.7 & 733 & 0.7 & 5153 & 4.8 & 14,772 & 13.6 & 2410 & 2.2 \\
\hline
\end{tabular}

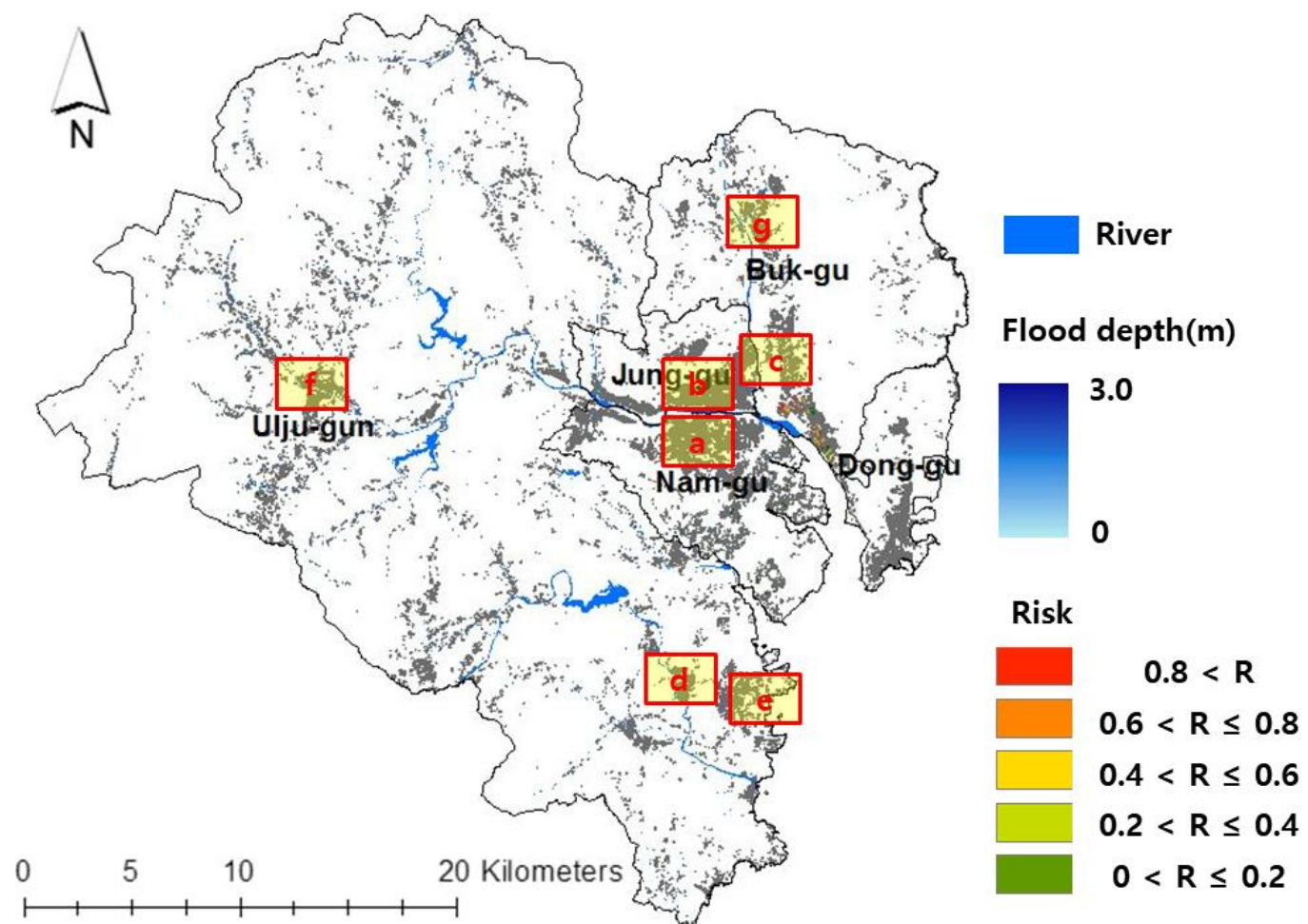

Figure 8. Classification by building on urban flood risk (key map). 


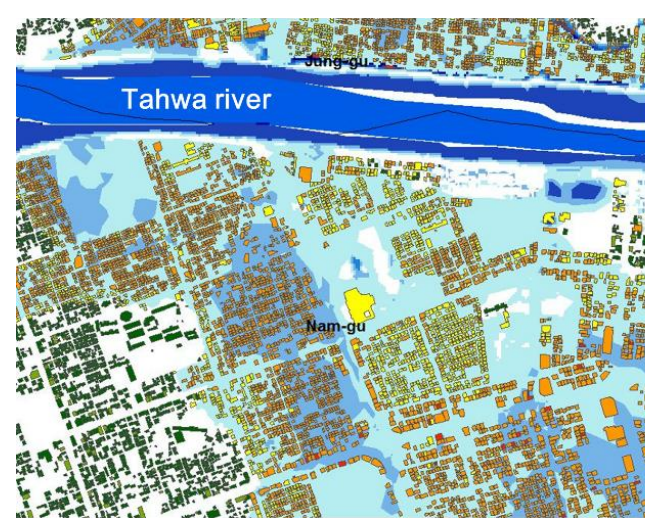

(a)
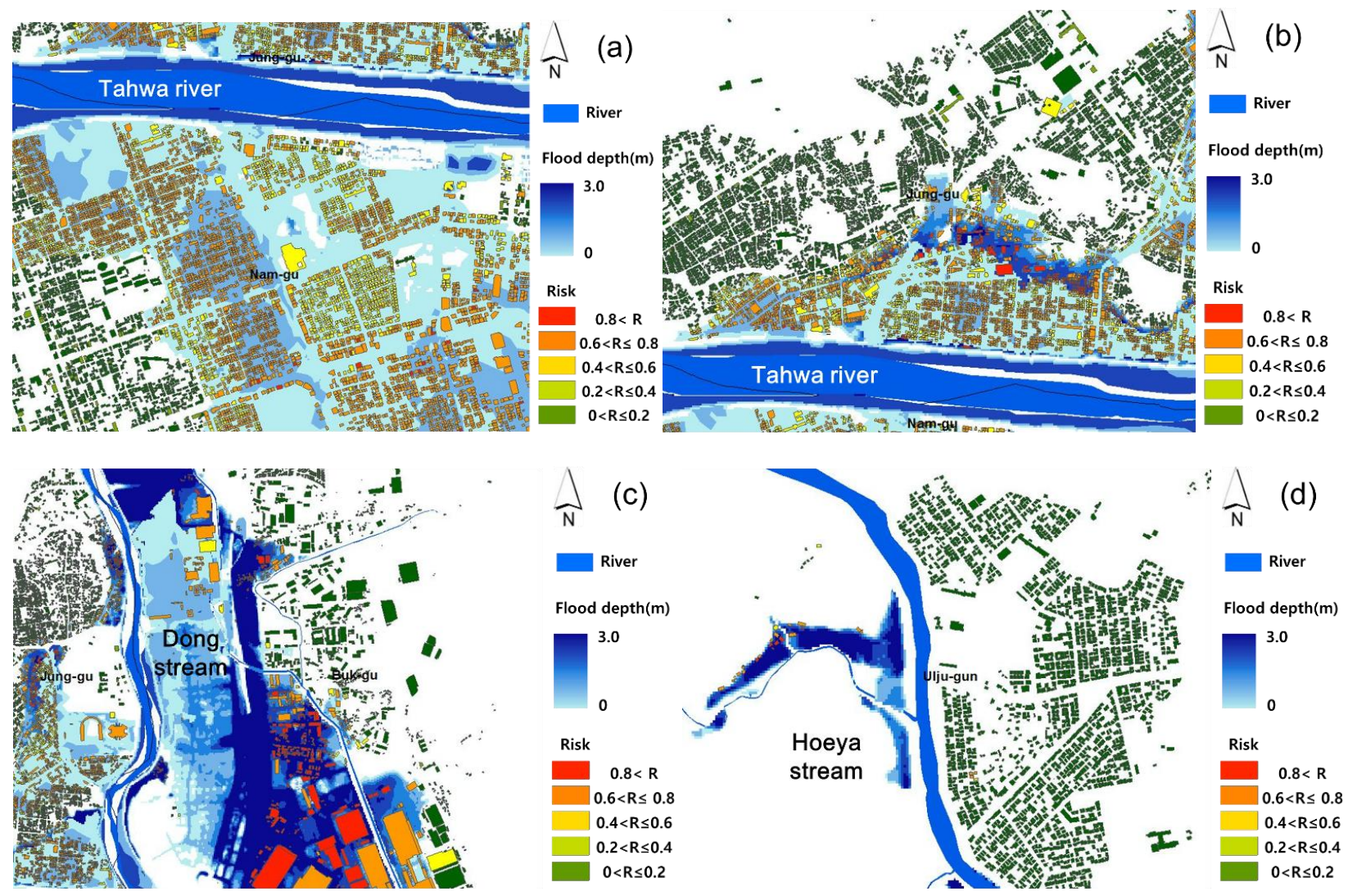

$\Delta_{N}(c)$

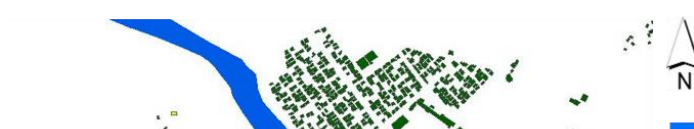

(d)
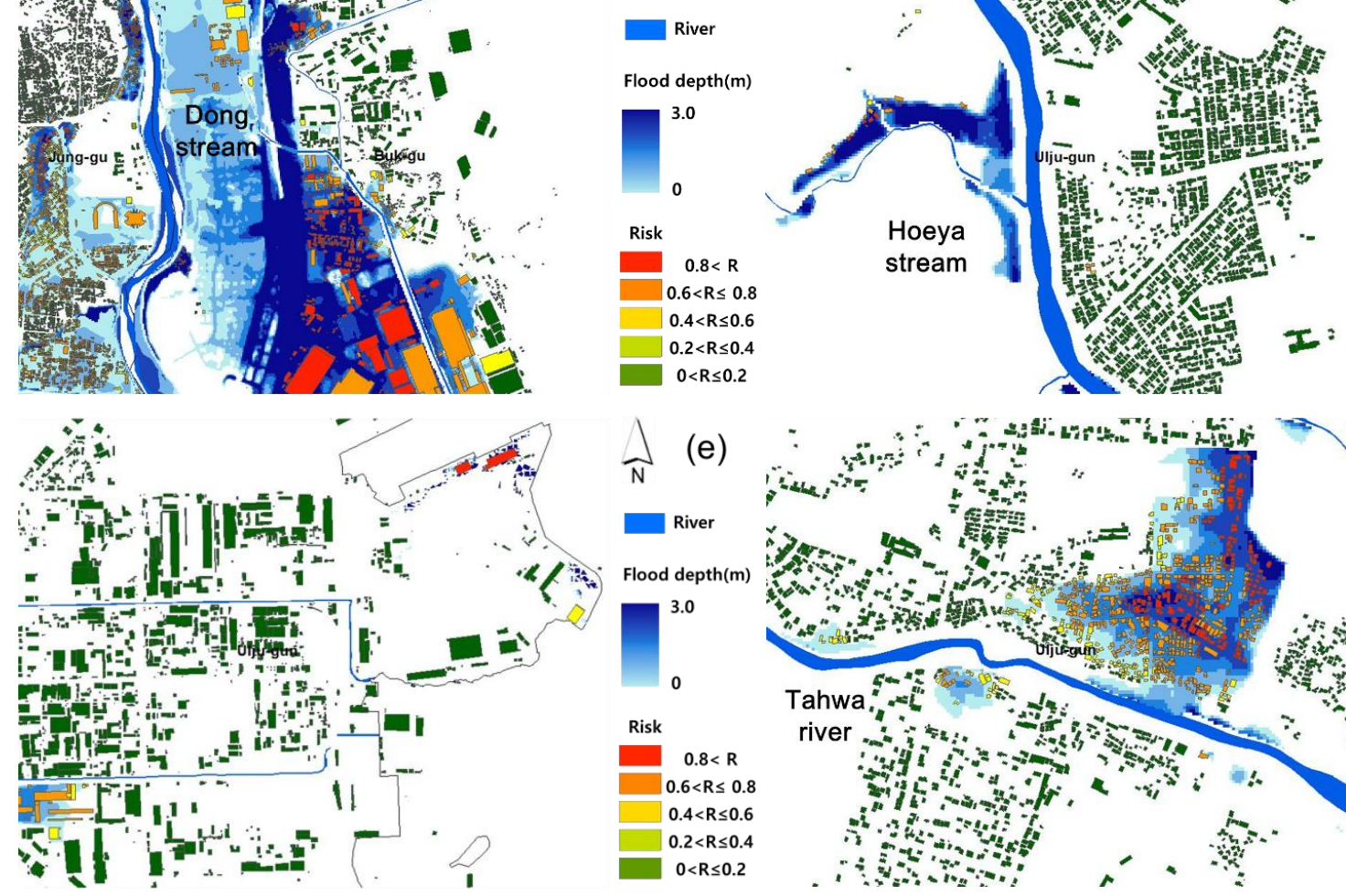

$\widehat{N}$

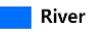

Flood depth(m)

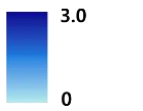

Risk

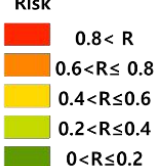

$\lambda_{N}(e)$
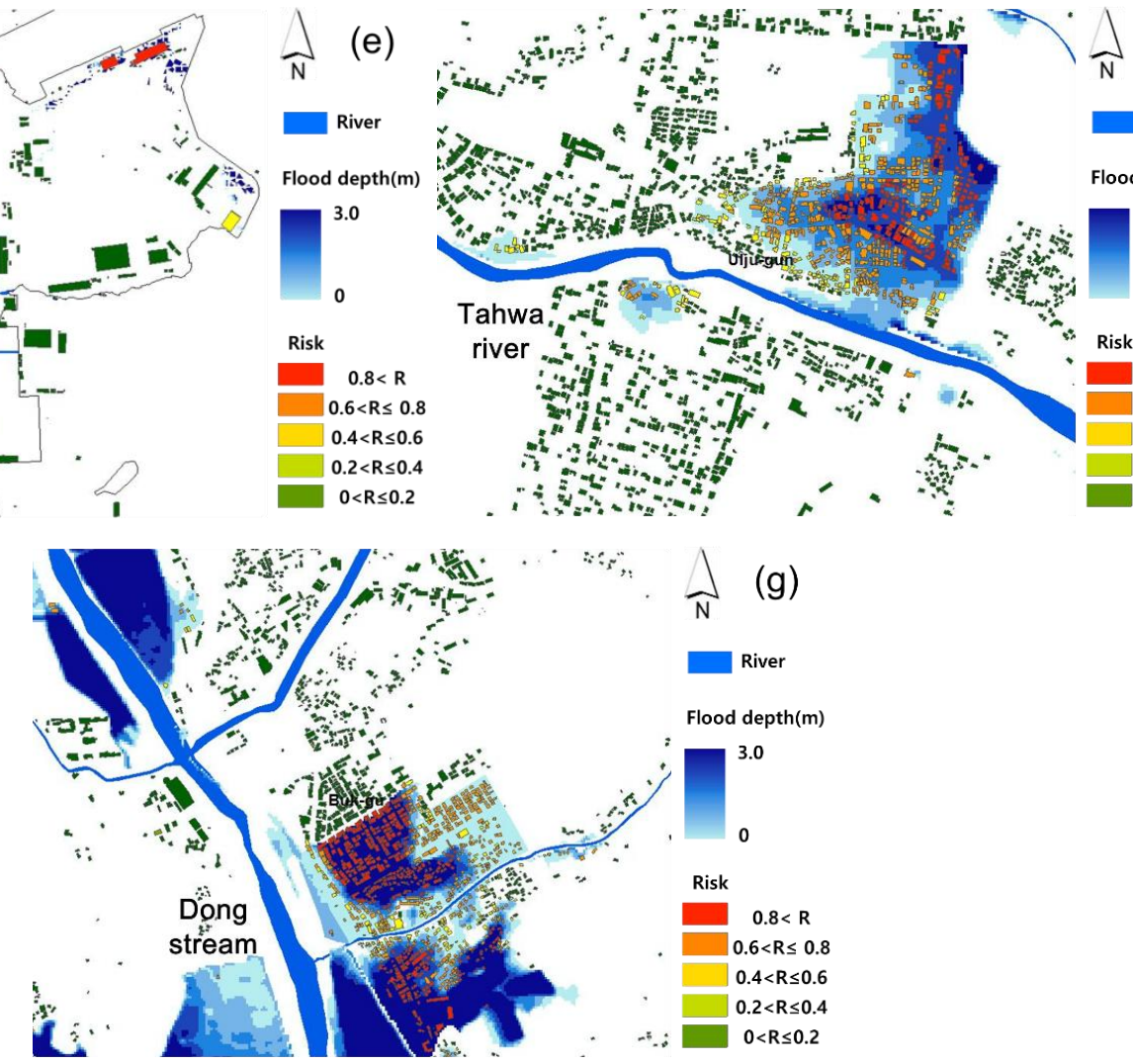

Figure 9. Micro view of classification by building on urban flood risk; Nam-gu district (a), Jung-gu district (b), South of the Buk-gu district (c), Buk-gu district near the stream (d), South of the Ulju-gun district (e), Ulju-gun district (f), North of the Buk-gu district (g). 
We studied flood risk analysis for each district and showed that the district where the red-class buildings (a very high urban flood risk) exhibits the highest distribution rate is Buk-gu (8.5\%). Then, the risk distribution rate of the red-class of flood risk decreases in the descending order of Ulju-gun (2.2\%) > Jung-gu (1.8\%) > Nam-gu (0.6\%) > Dong-gu (0.0\%). Nam-gu (26.3\%), Jung-gu (18.4\%), and Buk-gu (13.1\%) show a high distribution rate and belong to the orange risk class. The Dong-gu (98.5\%) and the Ulju-gun $(89.0 \%)$ districts were classified as the least-risk areas with a green code.

The Nam-gu district has the highest distribution rate of red and orange class buildings (Figure 9a). The active stage of urbanization and the construction of residential areas has recently begun in the Nam-gu district. The Ulsan petrochemical complex and industrial cluster are built centering around the Ulsan City Hall and public institutions. Therefore, its exposure level is high because the Taehwa river flows in the northern part of this region. The Ulsan port and the Jangsaengpo port are located on the eastern side, giving a strategical transportation advantage for this district, whereas the business area that had been developed early is nowadays revitalized. We identified numerous buildings with high risk as the high-density business area has a significant territorial span as numerous buildings with high property values are present in this district.

The Buk-gu district is shown in Figure $9 c, g$. The exposure of the Figure $9 \mathrm{c}$ region is relatively high since the Dong stream is flowing on the left side of this area. Moreover, the Ulsan airport and the industrial complex in this district and most buildings were constructed with abundant basement facilities. Similarly, the Dongcheon river flows on the left side of the Figure $9 \mathrm{~g}$ district where an abundance of red and orange class buildings was established (in the Maegok General Industrial Complex near the Maegok river flowing from the Maegok reservoir located upstream). Thus, it can be concluded that the Figure $9 \mathrm{~g}$ district is a high-risk region.

The Jung-gu district is shown in Figure 9b. Since this area had been developed at the early stage of the modern development of Ulsan, several deteriorated buildings are now located in Jung-gu. Currently, an innovation city is being established (so-called "futuretype city") with the government support; thus, numerous buildings with high risk are found as the floor area ratio is increasing and the property value is increasing.

The Ulju-gun district is shown in Figure $9 \mathrm{~d}-\mathrm{f}$. Because this area is mostly composed of mountain lands and green areas centering around the Sinbulsan national park, the number of buildings in the area was found to be very low. The flood risk analysis results indicate that most buildings can be included in the green class. The Dong-gu district has no buildings of red or orange classes, indicating that this area is relatively safe. In the Ulju-gun and the Dong-gu districts, villages were formed centering around the mountain lands and green areas. In these districts, buildings are broadly distributed, but these areas are mostly developed as environmental and conservational clusters; thus, most buildings there belong to the green (i.e., safe) class.

To summarize, the districts formed around rivers and streams have plausibly high exposure to flood risk. These districts are included in a danger area and such classification is supported by the urban flood risk analysis for each building. The urbanization efforts are vectorized in the lowland regions with low exposure to increase the convenience and effectiveness of civic infrastructure. We showed that the impermeable area rather than the green area was formed in the analyzed areas, thus making these regions high-danger areas. Furthermore, any region where high-density urban development occurred has a high property value and high vulnerability, which in turn results in a high risk.

\section{Conclusions}

Currently, society is suffering from numerous severe environmental phenomena; however, existing urban development practices to address these were established much earlier. The frequency and the intensity of the damage caused by natural disasters are gradually increasing because of climate change and global warming. Thus, the necessity for disaster management and prevention in the urban areas is urgent from a long-term 
perspective. It is widely known that the growth-oriented development was initiated without holistic planning for disaster prevention and safety regulations that should have been among the top priorities in urban development for mankind. Therefore, there are many vulnerabilities in the current urban structure in the face of natural disasters. To adapt urban infrastructure to climate change, the urban space should be efficiently modified through long-term flood risk assessment of buildings in cities.

Analysis of driver-specific and building-specific disasters revealed that the damage rate of heavy rain is the highest and buildings suffer the most damage from this natural phenomenon. This study was focused on the flood damage due to heavy rain while being focused on the buildings forming the urban spatial extent and the urban flood risk of the five regions in the Ulsan City. First, vulnerability and exposure analyses were conducted to examine the urban flood risk of each building type. The vulnerability analysis was conducted after selecting a building typical factor, a nonstructural factor that can affect the urban flood damage, expressed as an index. The areas with high vulnerability encompass a spatial cluster than includes some parts of the Jung-gu, Buk-gu, and Nam-gu districts. This spatial cluster plays a key role in the administration of the Ulsan City and is the most revitalized zone in this urban area.

The flood depth was analyzed in the exposure analysis by using environmental factors (precipitation and terrain), providing a basis for creating urban flood map. This analysis indicated that the flood depth of the lowland area adjacent to the Taehwa river and the Dong stream is high, and the topographical factor significantly affects urban development by reinforcing the urban flood risk. By mapping the results of vulnerability and exposure analysis, we speculated about the urban flood risk of each building type. In particular, each building type was classified into five risk-related classes (green, lime green, yellow, orange, and red) and the results are as follows. The red buildings were widely distributed across the old downtown area of the Buk-gu and the Ulju-gun districts. These districts were developed a long time ago; thus, their property value is currently reduced. The buildings are old, and their durability is weakened. Moreover, since the cities are topographically formed centering around the riverside lowlands, we concluded a high risk of flood. While special measures are required for aged buildings, high-risk buildings of this type represent only a minority as the red class encompasses only $2.2 \%$ among all buildings.

There was an abundance of orange class buildings in the high-density area centered around the Taehwa river. This area represents a spatial cluster in a triangular shape encompassing the Jung-gu, Buk-gu, and the Nam-gu districts. We emphasized that the same area consolidates numerous key functions of the Ulsan City and where the infrastructure of high socio-economic importance for Ulsan nowadays exists. It can be concluded that the development of the urban area considered accessibility to the center, effectiveness, and convenience for urban residents. This is an important aspect as it highlights the necessity of the holistic management of urban areas. We found that among the large-scale buildings, there were many yellow class buildings given the property value of the building and the existence of spatially extended basement areas within. Lime green and green buildings (relatively safe buildings) were found to be sporadically distributed in the outskirts of the city and in green residential areas where abundant vegetation is growing.

Our study allows extracting the space with high spatial risk based on the analysis of urban flood risk conducted for each building type. These results open prospects for formulating the advanced prevention measures and plans which can help in minimizing the long-term flood damage. The minimization of damage can be reached by preparing the nonstructural measures in the unit of land use and for each building in addition to the existing structural measures. In particular, appropriate and concrete land use plans can be established and recreational urban spaces such as green areas and open spaces (that reduce floods) can be placed in urban spaces in which buildings with a high risk are concentrated. Furthermore, a step towards tailored management should be made by coding the buildings. This will improve their durability as the disaster prevention facilities would be established for the buildings with high risk. If the prevention plan for buildings 
with a high flood risk is actively developed for the land use plans and being considered for a spatially extended area (not only as vector of development), the widespread urban flood damage can be minimized in the long term through systematic and effective management.

A nonstructural measure is difficult to quantify and analyze due to its qualitative aspects compared to a structural measure. However, it is necessary to investigate a longterm perspective of this issue as it can address the limitations of current structural measures. The results of this study can help further research on preparing nonstructural measures from various perspectives.

Author Contributions: Conceptualization, K.P.; data curation, I.Y.; project administration, S.-H.C.; Software, I.Y.; validation, K.P.; writing—original draft preparation, K.P.; writing—review and editing, K.P. All authors have read and agreed to the published version of the manuscript.

Funding: Please add: This research was funded by the National Research Foundation of Korea (NRF), grant number 2019R1I1A1A01063200.

Institutional Review Board Statement: Not applicable.

Informed Consent Statement: Not applicable.

Data Availability Statement: Not applicable.

Acknowledgments: This research was supported by Basic Science Research Program through the National Research Foundation of Korea (NRF) funded by the Ministry of Education (2019R1I1A1A01063200).

Conflicts of Interest: The authors declare no conflict of interest.

\section{References}

1. Jonkman, S.; Vrijling, J. Loss of life due to floods. J. Flood Risk Manag. 2008, 1, 43-56. [CrossRef]

2. Collet, L.; Beevers, L.; Prudhomme, C. Assessing the Impact of Climate Change and Extreme Value Uncertainty to Extreme Flows across Great Britain. Water 2017, 9, 103. [CrossRef]

3. Guha-Sapir, D.; Below, R.; Hoyois, P. Natural Disasters Reported; EM-DAT International Disaster Database, Université Catholique de Louvain: Brussels, Belgium, 2015.

4. Elkhrachy, I. Flash Flood Hazard Mapping Using Satellite Images and GIS Tools: A case study of Najran City, Kingdom of Saudi Arabia (KSA). Egyp. J. Remote Sens. Space Sci. 2015, 18, 261-278. [CrossRef]

5. Forkuo, E.K. Flood hazard mapping using aster image data with GIS. Int. J. Geomat. Geosci. 2010, 1, 932-950.

6. Gigović, L.; Pamučar, D.; Bajić, Z.; Drobnjak, S. Application of GIS-Interval Rough AHP Methodology for Flood Hazard Mapping in Urban Areas. Water 2017, 9, 360. [CrossRef]

7. Didovets, I.; Krysanova, V.; Bürger, G.; Snizhko, S.; Balabukh, V.; Bronstert, A. Climate change impact on regional floods in the Carpathian region. J. Hydrol. Reg. Stud. 2019, 22, 100590. [CrossRef]

8. Popa, M.C.; Peptenatu, D.; Drăghici, C.C.; Diaconu, D.C. Flood Hazard Mapping Using the Flood and Flash-Flood Potential Index in the Buzău River Catchment, Romania. Water 2019, 11, 2116. [CrossRef]

9. Du, S.; Shi, P.; Van Rompaey, A.; Wen, J. Quantifying the impact of impervious surface location on flood peak discharge in urban areas. Nat. Hazards 2015, 76, 1457-1471. [CrossRef]

10. Ogden, F.L.; Raj Pradhan, N.; Downer, C.W.; Zahner, J.A. Relative importance of impervious area, drainage density, width function, and subsurface storm drainage on flood runoff from an urbanized catchment. Water Resour. Res. 2011, 47, 1-12. [CrossRef]

11. Suriya, S.; Mudgal, B.V. Impact of urbanization on flooding: The Thirusoolam sub watershed-A case study. J. Hydrol. 2012, 412-413, 210-219. [CrossRef]

12. Cabrera, J.S.; Lee, H.S. Flood-Prone Area Assessment Using GIS-Based Multi-Criteria Analysis: A Case Study in Davao Oriental, Philippines. Water 2019, 11, 2203. [CrossRef]

13. Thomas, V.; Albert, J.R.G.; Hepburn, C. Contributors to the frequency of intense climate disasters in Asia-Pacific countries. Clim. Chang. 2014, 126, 381-398. [CrossRef]

14. Thampapillai, D.J.; Musgrave, W.F. Flood damage mitigation: A review of structural and nonstructural measures and alternative decision frameworks. Water Resour. Res. 1985, 21, 411-424. [CrossRef]

15. Scionti, F.; Miguez, M.G.; Barbaro, G.; Sousa, M.M.D.; Foti, G.; Canale, C. Integrated methodology for urban flood risk mitigation in cittanova, Italy. J. Water Resour. Plann. Manag. 2018, 144, 05018013. [CrossRef]

16. Andjelkovic, I. Guidelines on Non-Structural Measures in Urban Flood Management; International Hydrological Programme (IHP); United Nations Educational, Scientific and Cultural Organization (UNESCO): Paris, France, 2001.

17. Egli, T. Non-Structural Flood Plain Management: Measures and Their Effectiveness; International Commission for the Protection of the Rhine (ICPR): Koblenz, Germany, 2002. 
18. Roy, E.; Rousselle, J.; Lacroix, J. Flood damage reduction program (FDRP) in quebec: Case study of the chaudiere River. Nat. Hazards 2003, 28, 387-405. [CrossRef]

19. Kreibich, H.; Thieken, A.H.; Petrow, T.; Müller, M.; Merz, B. Flood loss reduction of private households due to building precautionary measures-lessons learned from the Elbe flood in August 2002. Nat. Hazards Earth Syst. Sci. 2005, 5, 117-126. [CrossRef]

20. Park, K. Flood Risk Assessment Modelling Reflected upon Vulnerability and Exposure. Ph.D. Thesis, Chungbuk National University, Cheongju, Korea, 2018; pp. 1-179.

21. Ministry of the Interior and Safety. 2019 Statistical Yearbook of Natural Disaster; Ministry of the Interior and Safety: Seoul, Korea, 2020.

22. Ulsan Metropolitan City. 2030 Urban Masterplan for Ulsan; Ulsan Metropolitan City: Ulsan, Korea, 2016.

23. Park, K.; Yu, I. Evaluating the vulnerability of buildings to urban flooding using the fuzzy inferences method. Desalin. Water Treat. 2020, 183, 88-103. [CrossRef]

24. Park, K.; Won, J. Analysis on distribution characteristics of building use with risk zone classification based on urban flood risk assessment. Int. J. Disaster Risk Reduct. 2019, 38, e101192. [CrossRef]

25. Water Directors, Core Group on Flood Protection of the Water Directors. Best Practices on Flood Prevention, Protection and Mitigation; European Initiative on Flood Prevention; EU: Brussels, Belgium, 2003.

26. Yevjevich, V. Technology for Coping with Floods in the 21st Century. NATO ASI Ser. 1994, 257, 35-43.

27. Anita, J. Structural and Non-Structural Approaches as Flood Protection Strategy in Muara Angke Settlement, North Jakarta. In Proceedings of the Second International Conference on Sustainable Infrastructure and Built Environment, FTSL, ITB, Bandung, Indonesia, 19-20 November 2013.

28. Petry, B. Coping with Floods: Complementarity of Structural and Non-Structural Measures; Science Press: New York, NY, USA, 2002; ISBN 1-880132-54-0.

29. IPCC. Climate Change 2014: Impacts, Adaptation, and Vulnerability. Part A: Global and Sectoral Aspects, Contribution, of Working Group II to the Fifth Assessment Report of the Intergovernmental Panel on Climate Change; Cambridge University Press: Cambridge, UK; New York, NY, USA, 2014; pp. 1-1132.

30. Kim, S.J.; Park, S.; Lee, S.J.; Shaimerdenova, A.; Kim, J.; Park, E.; Lee, W.; Kim, G.S.; Kim, N.; Kim, T.H.; et al. Developing spatial agricultural drought risk index with controllable geo-spatial indicators: A case study for South Korea and Kazakhstan. Int. J. Disaster Risk Reduct. 2021, 54. [CrossRef]

31. Cai, T.; Li, X.; Ding, X.; Wang, J.; Zhan, J. Flood risk assessment based on hydrodynamic model and fuzzy comprehensive evaluation with GIS technique. Int. J. Disaster Risk Reduct. 2019, 35. [CrossRef]

32. GIZ; Eurac. Risk Supplement to the Vulnerability Sourcebook; GIZ: Bonn, Germany, 2017. 